\title{
INJUNCTION AND RECEIVERSHIP PROCEEDINGS AGAINST ILLEGAL LENDERS
}

\author{
EMMET R. FIRLD*
}

Loan sharks are not usually imbued with respect for law. Evasion of the various legal controls is indispensable to the success of their enterprises, and, operating as they do outside the law, they inevitably acquire a contempt for that which they have profitably defied by means of their various stratagems. The lawless attitude of those engaging in loan shark enterprises is a foremost reason why the loan shark continues to thrive and the problem he creates remains a serious one, despite a marked increase in recent years in the number and scope of regulatory laws relating to the field of consumer lending.

Everywhere the baneful effects of usury are recognized, and in every jurisdiction the state has undertaken to prescribe some measure of protection for its people from the harsh results arising from unconscionable exactions for the use of money. Experience has demonstrated that legislation unaccompanied by vigorous and continuous policing action is not enough. The inherent limitations of criminal prosecutions necessitate the use of other weapons, and in a substantial number of jurisdictions the exaction of usury is not a crime and resort to the criminal law is not there available. The illegal lender's methods are designed to place the borrower in a position where he cannot thake use of ordinary remedies, the legal machinery available to the borrower is often too cumbersome, expensive and otherwise inaccessible, and the prosecution of actions by individual victims seeking redress has nowhere seriously retarded the loan shark's vicious practices. The victims themselves are usually uninformed persons who are incapable of defending their own interests or even of affording the time and money necessary for the litigation attendant upon a defense, while the lenders with whom they deal invariably possess resources and employ methods far beyond the power of their victims to oppose. The enormous aggregate operations of loan sharks, their disregard and planned circumvention of private rights, their calculated and defiant contempt for law, their brazen use of minor courts as weapons of oppression, and the devastating effects of their piratical onslaught upon millions of obscure people clearly provide a problem of general concern and one which defies solution by unorganized, individual attacks.

From these conditions the state itself emerges as the logical champion of its own

* LL.B., I917, University of Louisville. Member of the Kentucky Bar. General Counsel, Legal Aid Society of Louisville. Member, Executive Committee, National Association of Legal Aid Organizations. 
unfortunate citizens who are the actual and potential victims of loan sharks. In championing them the state, in a number of jurisdictions, has sought to eliminate the operation of illegal lending enterprises by resort to the equitable remedies of injunction and receivership. In the interesting litigation ensuing some conflict between traditional views limiting the scope of these remedies and the necessity for an expansive application of them to the changed conditions and new problems engendered by our complex and ruthless modern era is apparent. The expansive attributes of equity are nowhere more strikingly described than in the old English case of Taylor v. Salmon," wherein Lord Chancellor Cottingham stated that, "It is the duty of a court of equity, in common with all courts and all institutions, to adapt its course of proceedings as far as possible to the needs of the existing state of society, and to apply its jurisdiction to all those new cases which, from the progress daily making in the affairs of men, must continuously arise, and not, from too strict adherence to forms and rules established under very different circumstances, decline to administer justice to enforce rights for which there is no other remedy." The basic jurisdiction of equity, the position of the state in relation to the public welfare, and the consequent relation of the courts to the state were clearly illustrated by the Supreme Court of the United States in In re Debs, ${ }^{2}$ wherein the court announced that "Every government, entrusted, by the very terms of its being, with powers and duties to be exercised and discharged for the general welfare, has a right to apply to its own courts for any proper assistance in the exercise of the one and the discharge of the other, and it is no sufficient answer to its appeal to one of those courts that it has no pecuniary interest in the matter. The obligation which it is under to promote the interest of all, and to prevent the wrongdoing of one resulting in injury to the general welfare, is often of itself sufficient to give it a standing in court."

While the invocation of the remedy of injunction by the state in loan-shark cases is a relatively untested procedure, the ingenuity of lenders and their counsel has failed to evolve any convincing defensive argument based on the novelty of the situation, , and the defenses usually urged are venerable ones which have been repeatedly presented in injunction cases of all types; i.e., the lack of sufficient standing and interest

${ }_{4}$ Myl \& C. 134, 141 (1838).

${ }^{2} 158$ U. S. $564,584(1895)$.

The famous opinion of Chancellor Kent in Attorney General v. Utica Insurance Company, 2 Johnson, c. $37 \mathrm{I}$ (N. Y. $18 \mathrm{I} 7$ ) in which case the court refused to enjoin the carrying on of a banking business in violation of a state statute has been the basis of numerous decisions denying an injunction on the alleged grounds that "equity will not enjoin a crime," or that "the state has no pecuniary, interest in the subject matter," or that "no property rights are involved." The portion of Chancellor Kent's "opinion used as authority for these holdings is clearly dictum as has been frequently pointed out, for example, by the Supreme Court of Georgia in Trust Company of Georgia v. State, rog Ga. 736, 35 S. E. 823 (1900); and in any event is not supported even by the English authorities cited in support of it as has been many times pointed out by courts and text writers. E.g., see Attorney General v. Railway Companies, (1874) 35 Wis. 425, 549-50 (I874), and Caldwell, Injunctions Against Crim̀e, (I93I) 26 ILI. L. REv. 259, 26I. The Court of Appeals of New York itself, however, has finally and specifically repudiated its dictum in the Utica Insurance Company case in sustaining a complaint for injunction against the unlicensed practice of chiropractic. People ex rel. Bennett, Attorney General v. Laman, 277 N. Y. $368,1_{4}$ N. E. (2d) 439 (1938). The error of the great Chancellor, therefore, should be regarded as effectually corrected and its influence on future cases should rapidly disappear. 
of the petitioner to warrant the granting of the relief prayed, the existence of adequate remedies at law, the supposed inability of courts of equity to enjoin criminal acts, the absence of property rights resting in the state, and the absence of facts characterizing the lender's activities as a nuisance. The existence of the necessary public interest is customarily recognized where the state sues to protect its own interest as a juristic person, but such recognition is not so readily afforded where it sues in vindication of the social interests of the community at large, and it is in this latter field that loan shark cases lie.

Although the question is seldom elucidated, the issue in most cases is not whether the court has jurisdiction to grant an injunction but whether within the very broad limits of its jurisdictional powers it should as a matter of discretion do so, and the motivations of policy and expediency which influence one chancellor will be wholly without appeal to another. It appears, however, that whenever the court is made to feel that the continuing unlawful acts constitute a direct threat to some recognized and important common interest, such acts will be enjoined. Courts may well differ in their views upon what constitutes a threat or an injury to the public good and upon what methods are the most adequate in affording protection; but when the decision is once made, the remedy is not to be blocked by outmoded principles of validity which arose in other settings, and the more courageous and enlightened courts have frankly taken such a stand. Their opinions are not always free from references to venerable doctrines, superimposed in supposed support of the decision, but the principle of direct action is boldly employed with effective results. It is not accurate to consider that the doctrine of the equitable prevention of public wrongs extends the jurisdiction of equity. Rather does it demonstrate the inherently expansive quality of that jurisdiction which permits adaption of its remedies to the changing needs of society and enables equity to perform its mission.

The-first case in which the right of the state to injunctive relief against the unlawful acts of loan sharks was established was State v. McMahon, ${ }^{3}$ decided in Kansas in I929. The public wrong arose in the fact that the defendant's business was the exaction of exorbitantly usurious and illegal rates of interest from numerous small wage earners, while the injury to the public welfare lay in the further fact that these exactions had reduced hundreds of these needy victims to financial peonage. The contention that the borrower's individual civil remedies afforded them adequate remedy at law was rejected, inasmuch as only in rare instances were the borrowers in a sufficiently strong economic position to enable them to effectively insist upon their individual rights. While it was not so stated, this fact clearly intensified the element of public wrong, in that conditions created and methods pursued by the lender tended largely to deprive borrowers of the equal protection of the laws. The court based its decision upon the principle expressed in the Debs case, and while finding that the acts complained of constituted a public nuisance, the issuance of an

s28 Kan. 772, 280 Pac. 906 (r929). 
injunction was predicated upon a recognition that the injury to social and economic welfare constituted its own justification for injunctive protection.

In the Kentucky case of Commonwealth $v$. Continental Co., the court, basing its decision upon the doctrine expressed in the Debs case, held that injunction was the proper remedy to terminate violations of the state's act regulating the small loans business. The inclusion in the act of penalties for its violation was considered as not intending the creation of a crime but merely to provide incidental means of enforcing the act for the public benefit, and for this reason the penalties section did not provide a remedy at law sufficient to preclude an appeal to equity. It was held that the state's obligation to protect the general welfare gave it a sufficient standing in court, ". . . to obtain an injunction ... . although the subject matter involved may not constitute a public nuisance." The decision was grounded solely upon the right of the state to injunctive relief against activities threatening the welfare of the community as a whole, and inferentially at least the reasoning of the lower court, in refusing an injunction on the grounds that no nuisance was involved and the criminal laws provided adequate legal remedy and insured to the defendant the right of trial by jury, was disapproved.

In the recent Florida case of State $v$. Gillian, ${ }^{5}$ an injunction was sought to prevent the continuance of a loan shark business operating in violation of the civil and criminal laws of Florida. The Supreme Court dismissed a writ of certiorari for review of the lower court's refusal to dismiss the amended complaint and its overruling of a demurrer thereto, on the ground that under the allegations of the amended complaint the plaintiff might be able to show that the respondents indulged in unlawful practices constituting a menace to public welfare, and that if these facts were shown, the state might invoke the aid of the chancery court to enjoin their continuance.

The record, however, has not been one of complete success on the part of the state in such cases. The court refused an injunction in the Tennessee case of State ex rel. Thompson $v$. Dixie Finance $\mathrm{Co}^{6}$ because, among other reasons, the jurisdiction to afford the relief depended upon the existence of a statutory or common law nuisance not present in the situation involved. In People v. Seccombe, ${ }^{\top}$ a California case, the district court of appeals refused an injunction sought against loan-shark activities. The decision is really based upon deficiencies of pleading, in that the pleader relied upon conclusions, and failed, or was unable, to allege facts taking the case within the extremely narrow limits of the California nuisance statute. The holding, limited to questions of pleading and the construction of the nuisance statute, is not authority for or against the inherent power of courts of equity to grant redress for public wrongs by injunctive relief at the instance of the state. This conclusion is strengthened by the fact that the action was instituted on relation of local officers of Los Angeles under a statute empowering such officials to sue to abate nuisances exist-

275 Ky. 238, 121 S. W. (2d) 49 (1938).

152 Tenn. 306, 278 S. W. 59 (1925).
193 So. 751 (1940).

${ }^{7}$ I03 Cal. App. 306, 284 Pac. 725 (1930). 
ing in their districts, and there was no joinder or formal approval by the attorney general of the state, so that consideration of the right of the state as parens patriae to invoke equitable relief in cases of public wrong was probably precluded.

In Ex Parte Hughes, ${ }^{8}$ a Texas case, the court declined to concede the right of the state to sue for an injunction to prevent the usurious practices of a loan shark, on the primary ground that the court lacked jurisdiction to entertain suits to abate nuisances, except where the action was directly authorized by constitution or statute, and no law existed directly authorizing an equity action by the state to enforce the usury laws. It was indicated that no nuisance and no property rights were involved, the remedies provided by the criminal law were considered adequate, and the state had no interest in the wholesale exaction of usury. It may be suggested that the court was overtechnical and far too modest in its notion of its own powers.

If the right to injunctive relief is once established, the court may grant such other incidental relief as may be necessary to insure the effectiveness of the injunction. A receiver may be appointed, when necessary, as an incident to the power to grant an injunction, for the purpose of making the injunction effective and to provide complete and effective redress of the wrongs to be remedied. In United States $v$. American Tobacco Co. ${ }^{9}$ the Supreme Court of the United States provided for the appointment of a receiver in aid of injunctive relief, the Court stating that a receiver ought to be appointed whenever necessary to enable the court "to award relief coterminous with the ultimate redress of the wrongs [found] to exist." In the Indiana case of Columbian Athletic Club v. State, ${ }^{10}$ the state petitioned for an injunction against the continued operation of a prize-fighting enterprise allegedly constituting a public nuisance. It also asked the appointment of a receiver for the properties used on the ground that the Club would fraudulently assign its rights and property to third parties so that prize fights might still be conducted notwithstanding an injunction, whereupon the court observed that if the offender might transfer its rights and property during the pendency of the action and so continue the acts complained of in the very face of the court, the whoie proceeding would become a mockery. A receiver was appointed because the court considered that the injunction would not of itself be sufficient to restrain the nuisance, the court stating that "The receivership in this case is not necessarily for the sequestration and sale of the property, but only to take charge of the same ... in aid of the injunction."

In a number of instances receivers have been appointed in aid of injunctions granted in loan shark cases. But in the Missouri case of Kansas City v. Markham,11 an attempt to utilize the receivership remedy in support of an injunction in a loan shark proceeding ran afoul of the traditional property interest rule and was buried beneath an avalanche of judicial disapproval. The main ground relied on for a receiver was that the defendants were about to dispose of their property to individuals beyond the jurisdiction of the court with the intent to render the judgment of the

r33 Tex. 305, 129 S. W. (2d) 270 (1939).

${ }^{10}$ I 43 Ind. 98,40 N. E. 914 (I895). 222r U. S. 106, 185 (Igrt).

${ }^{11} 339$ Mo. 753, 99 S. W. (2d) 28 (1936). 
court ineffectual. The circuit court appointed a receiver and the latter took over the records and property of the defendant. The latter appealed from the circuit court's refusal to revoke the appointment, and the circuit court was directed to vacate its appointment and to restore the property to the defendant. The controlling reason for the reversal was that the appointment of a receiver is improper unless the petitioner is able to show that he has a clear right or an apparent right or title in the property sought to be impounded, or some lien upon it, or that the property constitutes a special fund to which he has the right to resort for the satisfaction of his claim. The court held further that inasmuch as his appointment was without right, the receiver's taking of the property violated a constitutional guarantee against unlawful search and seizure, and the court in effect condemned the proceeding as a subterfuge to dragoon evidence from the defendant's records.

The court's requirement that the petitioner must show a title or other definite material interest in the property or go without a receiver indicates a failure to comprehend the basic nature of receiverships. Obviously, receivership is an in rem proceeding; if there is no property, there can be no receiver. But the involvment of property in an equitable action is merely the incident which permits, in proper case, the use of the receivership process. The remedy is not employed as a means of determining the merits of the case or the title to the property inter partes, nor can it be used for either purpose. Its sole office, in respect to the property, is to hold it in status quo until the court can decide upon the merits of the action and thereby determine what the rights and interests of the parties in the property are. The remedy is an ancillary one, purely. It is not the object of the action, but is an implementary means to the attainment of that object, in that it is a tool which may be utilized by the court so that it may give complete and effective relief. The Indiana court recognized this characteristic of the receivership process and upheld the appointment of a receiver to prevent the defendant from escaping the effect of an injunction. Thus where an injunction is granted, the court, upon a proper showing, frequently must appoint a receiver to prevent a nullification of the injunction and a consequent circumvention of justice. The true definition of the process arises from its capacity of enabling courts to administer complete justice; and courts have the right to emplov their own processes to maintain their integrity; and the remedy can hardly be accepted as a part of our procedure on the shallow ground that it is merely a special perquisite of litigants who are able to show a property interest.

During the year following the Markham decision, the Kansas courts determined an action which proceeded in a manner directly opposite to the course of the Markham case. In State ex rel. Beck v. Basham, ${ }^{12}$ the state sought to enjoin the defendant from conducting a loan-shark venture in flagrant violation of the statute relating to interest rates and requested the appointment of a receiver for the defendant's business. The lower court held that the state failed to establish facts sufficient to justify an injunction and receiver, but on appeal this holding was reversed and an injunction

12 I 6 Kan, $18 \mathrm{r}, 70$ P. (2d) 24 (1937). 
and the appointment of a receiver were directed. The defendant's contention that inasmuch as the violation of the usury statute was not a crime the relief requested by the state could not be granted did not impress, the court considering that because criminal action could not be maintained an injunction became even more appropriate. The defendant also put forward the defense that inasmuch as the proof showed that he did not use harsh collection methods, or often attach wages, or deceive borrowers as to the fact that they were paying illegal interest, the conduct of his business did not amount to a nuisance. The court refused to be deceived by this wolf-in-sheep'sclothing disguise, and held that the defendant's own evidence established that he continuously violated the usury statute and that this persistence of lawlessness constituted a nuisance.

It is important to note that the court did not, however, rest its decision solely upon the doctrine of nuisance, for, said the court, "We are not convinced defendant's conduct has to be characterized as a nuisance before it can be enjoined." The court's opinion contains no discussion of the grounds or propriety of the receivership, and in view of the nature of the case and the completeness of the relief sought and granted, it seems clear that throughout the proceeding the receivership was treated as being solely for the purpose of giving absolute effect to the injunction and was to be accepted as being solely in aid of the injunction.

The Minnesota Supreme Court upheld orders enjoining the operation of a loan shark business and appointing a receiver in the case of State ex rel. Goff v. O'Neil.13 The usury law did not make usurious exactions a crime, but the court pointed out that the usury law established the policy of the state with reference to interest and outlawed the taking of usury, in the interest of public welfare, and defendant's conduct was held to constitute a nuisance under the state's broad nuisance statute, and the state's right to an injunction where there was no adequate remedy by criminal law or ordinary civil suit was upheld. In approving the receivership the court noted that the defendant, by his own showing, admitted that some of his transactions were usurious and failed to show that any of his loans. were free from usury. The court then considered the receiver's report, which revealed that every loan recorded in the defendant's books was scandalously usurious, whereupon the court came to this conclusion: "In this situation should defendant's books and evidence of the usurious debts be restored to him? If the notes are disposed of and reach bona fide purchasers for value before maturity, the defense of usury is not available. The court should not give an opportunity for this to happen." There followed an attempt to show a species of interest in the state in such usurious payments as might have been recoverable, in that if recovered by a public officer half the recovery was required to be paid into the county school fund, but the reasoning is not convincing, and two judges who agreed with the majority in approving the injunction declined to agree as to the propriety of the receivership, their dissent resting upon the familiar view that the state lacked the kind of interest in the defendant's property which would justify the

${ }^{28} 205$ Minn. 366,286 N. W. 316 (1939). 
receivership remedy. Nevertheless, the case is a stimulating one. At the outset the court took appreciative note of the embarrassing position assumed by the defendant when he admitted, by his answer, that he was up to his arm pits in iniquity, as the bill charged. Thenceforward the court declined to be deterred by conventional views as to its powers, set out to provide a complete remedy, upheld the receivership, considered the information lifted by the receiver from the defendant's files, took the most direct route in getting at the truth, and thereby secured the devastating effect of the best evidence.

The continued expansion of regulatory laws is not a complete answer to the loan shark evil. There will always be unscrupulous people who are inherently incapable of submitting to the regulating influences of law and order. The loan shark is of that character. He will continue to prey upon the weaker members of the community and will calculatingly evade all of the controlling influences of society for as long as he is able to secure the exorbitant profits which are the rewards of his lawlessness. He cannot exist without exacting usury, there is no middle ground upon which he may operate, and so long as he declines to submit to the rules of society and to conduct his business in a lawful manner the only complete remedy is the liquidation of his piratical enterprise. A remedy which impounds the instruments evidencing usury as well as the account sheets and other records of the illegal lender not only prevents their physical removal beyond the reach of the court, but permits the illumination of the methods of a business which can least afford the glare of publicity. In suppressing the evil, injunction and receivership are not the only weapons available, but they are among the most deadly. 